\title{
Disruption of Glycolysis, TCA Cycle, Respiratory Chain, Calcium and Iron Homeostasis in Doxorubicin Induced Cardiomyopathy-An In-silico Approach
}

\author{
Uma Priya Mohan ${ }^{1}$, Selvaraj Kunjiappan ${ }^{2}$, Tirupathi Pichiah P.B. ${ }^{3}$, Sankarganesh Arunachalam ${ }^{1, *}$ (ID \\ 1 Center for Cardiovascular and Adverse Drug Reactions, Department of Biotechnology, School of Bio and Chemical \\ Engineering, Kalasalingam Academy of Research and Education, Krishnankoil, Virudhunagar Dt., Tamilnadu, India - \\ 626126 \\ 2 Department of Biotechnology, School of Bio and Chemical Engineering, Kalasalingam Academy of Research and \\ Education, Krishnankoil, Virudhunagar Dt., Tamilnadu, India -626126 \\ 3 Department of Animal Science, School of Life Sciences, Bharathidasan University, Tiruchirappalli, Tamil Nadu, India - \\ 620024 \\ * Correspondence: sankarganesh@gmail.com (S.A.);
}

Scopus Author ID 35209520500

Received: 29.10.2021; Revised: 29.11.2021; Accepted: 2.12.2021; Published: 12.12.2021

\begin{abstract}
Doxorubicin is a well-known anthracycline antibiotic that is frequently used to treat a variety of malignancies. However, its clinical use is limited due to its adverse consequences, most notably cardiomyopathy. In the present work, we evaluated the molecular mechanisms behind the impairment of cardiac energetics in doxorubicin-induced cardiomyopathy. According to molecular docking, the interaction of doxorubicin with phosphofructokinase (PKF) and $\alpha$-enolase is likely to negatively affect glycolysis. The interaction between doxorubicin with HMOX1 results in the accumulation of free iron. The free iron contributes to the heme-driven toxicity and the oxidizing environment that results in reactive oxygen species (ROS) production resulting from cell death. Additionally, the interaction of doxorubicin with HMOX1 impairs the availability of iron required for the Krebs cycle and ETC function. The interaction between doxorubicin and PINK1 results in a reduced membrane potential, which results in calcium accumulation. On the other hand, a lack of iron and calcium in the mitochondrial matrix results in ATP depletion, impairing the Krebs cycle activity. At the same time, the primary cause of doxorubicin-induced cardiomyopathy is cardiac energy metabolism. Thus, our work shows that doxorubicin impairs the activity of PFK, $\alpha$-enolase, HMOX1, and PINK1, resulting in ATP production failure. As a result of changes in the heart energy metabolism, this ultimately leads to dilated cardiomyopathy caused by doxorubicin. Understanding the critical function of cardiac energy metabolism in doxorubicin-induced cardiomyopathy is critical for overcoming the obstacles that effectively limit the clinical effectiveness of this life-saving anti-cancer treatment.
\end{abstract}

Keywords: doxorubicin; dilated cardiomyopathy; phosphofructokinase; $\alpha$-enolase; HMOX1 and PINK1.

(C) 2021 by the authors. This article is an open-access article distributed under the terms and conditions of the Creative Commons Attribution (CC BY) license (https://creativecommons.org/licenses/by/4.0/).

\section{Introduction}

Doxorubicin (DOX) is a very efficient chemotherapeutic anthracycline drug that cures various types of cancer types, including leukemia, lymphomas, breast cancer, etc. [1-5]. But its clinical application is limited by its cumulative and irreversible cardiotoxicity cardiomyopathy [6-8]. Various theories have suggested the mechanism of cardiomyopathy, but the exact mechanism is still unknown $[9,10]$. Several reports suggest that the dysfunction 
and alteration in mitochondrial physiology could be one of the underlying mechanisms in DOX-induced cardiomyopathy [11-13]. In addition, the ATP deficiency associated with DOXinduced cardiomyopathy can be correlated with alterations in mitochondrial energy metabolism and bioenergetics [14-16]. Mitochondrial metabolism is a prime source of ATP biosynthesis. As DOX ensues damage to the inner mitochondrial membrane, respiratory chain complexes are damaged, eventually diminishing ATP production [17,18].

Mitochondria generate the majority of cellular ATP via oxidative phosphorylation. Glycolysis, where glucose is converted to pyruvate's key product, starts the ATP metabolism in the cytoplasm [19]. Pyruvate is transported into the mitochondria and metabolized by the citric acid cycle. During the citric acid cycle, the coenzymes nicotinamide adenine dinucleotide $\left(\mathrm{NAD}^{+}\right)$and flavin adenine dinucleotide (FAD) are reduced and produce $\mathrm{NADH}$ and $\mathrm{FADH}_{2}$ (some NADH is also generated during glycolysis). These electron carriers are used by the electron transport chain (ETC), which provides energy for establishing a proton gradient across the mitochondrial inner membrane [20-22].

Electron transfer occurs along with a series of mitochondrial polypeptide complexescomplex I (NADH dehydrogenase), complex III (cytochrome c reductase), and complex IV (cytochrome c oxidase) - and is electrochemically coupled to proton translocation across the inner mitochondrial membrane, generating a proton-motive force composed of an electrical gradient $\left(\Delta \psi_{\mathrm{m}}\right)$ and an $\mathrm{H}^{+}$gradient $(\Delta \mathrm{pH})$. The mitochondria employ the mitochondrial membrane potential $\left(\Delta \psi_{\mathrm{m}}\right)$ for various activities, including the powering of mitochondrial ATP synthase [23,24]. The gradient is utilized to drive metabolism's last stage, oxidative phosphorylation. The phosphorylation of ADP occurs when protons flow down this gradient via the ATP synthase complex, providing the energy to phosphorylate ADP to ATP. This is the principal way that the ATP is synthesized in most eukaryotic cells [20].

Interestingly, iron homeostasis and the citric acid cycle are interconnected. Subsequently, iron alarms the expression of a translational mechanism of the citric acid cycle enzyme mitochondrial aconitase. Moreover, iron regulates some of the enzymes in a citric acid cycle: citrate synthase, succinate dehydrogenase, and isocitric dehydrogenase. Thus, iron is indirectly involved in forming reducing equivalents (NADH) by the citric acid cycle. As a result, there is an increased mitochondrial oxygen consumption and ATP synthesis through oxidative phosphorylation [25-27].

Meanwhile, mitochondrial calcium regulates ATP synthesis, respiration, and ROS substrate-dependent $[27,28]$. Furthermore, calcium directly regulates the membrane potential $(\Delta \psi)$ for ATP synthesis. The nanomolar concentration of calcium enhances the potential membrane utilization, whereas the increased level of mitochondrial calcium hinders ATP synthesis by impairing membrane potential [21,29]. Thus, alteration in the mitochondrial calcium, iron homeostasis, glycolysis, citric acid, ETC renders ATP generation.

The objective of the present work is to understand the molecular factors of a progressive deterioration of cardiac energetics induced by doxorubicin. Understanding the interaction between the doxorubicin and cardiac energy metabolism in doxorubicin-induced cardiomyopathy is essential to reduce the barriers that so intensely limit the clinical success of this vital anti-cancer chemotherapeutic agent. Therefore, the current study highlights the interaction of doxorubicin with some enzymes/proteins involved in glycolysis, iron homeostasis, mitochondrial calcium, citric acid cycle, and ETC involved in the cardiac energetic metabolism were explored. 


\section{Materials and Methods}

\subsection{Protein target preparation.}

Protein targets were obtained from the Protein Data Bank (PDB). The Discovery studio visualizer 2020 was used to prepare the protein of interest [30]. The water molecules occupying the protein molecules were analyzed and removed wherever applicable. The bound ligands and ions were also eliminated. In general, PDB proteins are devoid of hydrogen atoms. As a result, hydrogen atoms were added to the protein to make it a typical protein. Furthermore, hydrogen atoms have a role in docking investigations. Finally, optimization and minimization methods were used to complete the protein production.

\subsection{Ligand preparation.}

Doxorubicin, the ligand, was obtained from the PubChem database. The molecules were constructed with the Discovery studio visualizer 2020, tuned to assure the ligand's lower energy isomer [30]. Following energy reduction, the ligand molecules performed molecular docking experiments.

\subsection{Molecular docking.}

In the current investigation, the prepared protein was imported into the workspace, and the active site was specifically stated using Uniprot. To cover all of the active site residues indicated by the site map, the grid was determined to be approximately $60 \AA$. Other parameters, such as the van der Waal's radii of the non-polar receptor and ligand atoms, were set to 0.50 by default. The best conformational posture was chosen based on the docking score, glide energy, hydrogen bonding, and hydrophobic bonding interactions.

\section{Results and Discussion}

\subsection{Interaction of Doxorubicin with enzymes involved in glycolysis.}

Glycolysis plays an essential metabolic pathway interconnected, and its intermediates are connected to several other pathways. It plays a significant role in synthesizing ATP in mitochondria [31]. Disruption/alteration in glucose utilization leads to the inadequate production of high-energy phosphates, which in turn causes impairment in relaxation and contractility in cardiac function [32]. Our earlier work with Saccharomyces cerevisiae suggests that doxorubicin affects glycolysis [30]. Doxorubicin strongly interacts with two of the enzymes in glycolysis. With phosphofructokinase, DOX binds at two amino acid residues from the enzyme's active site. Enolase is another enzyme affected by DOX by binding at two amino acid residues at the active site. [30] Therefore, in the current work, we analyzed the interaction of DOX with glycolytic enzymes in humans by molecular docking.

Our docking analyses showed that DOX interacts with phosphofructokinase, aldolase, and enolase. Among these three enzymes, DOX efficiently binds with phosphofructokinase and enolase, which agrees with our earlier results. [30] The binding free energies $\left(\Delta G^{\circ}\right)$ were found to be $-8.74 \mathrm{KJmol}^{-1}$ for phosphofructokinase and $-5.11 \mathrm{KJmol}^{-1}$ for enolase. The DOX and phosphofructokinase (PFK) interaction occurs through hydrophobic interactions with GLY 11, THR 125, ASP 129, ASP 103, ASP 127, ARG 171 ARG 292. The amino acid residue ARG 
292 lies within the substrate-binding site of the enzyme, which is likely to be affected by interacting with DOX. (Figure 1 and Table 1 and 2).

PFK is a critical glycolytic enzyme that catalyzes the conversion of fructose-6phosphate to fructose 1,6 bisphosphate. This is one of glycolysis' slowest reactions and a ratelimited process. Most significantly, this reaction initiates glycolysis, so PFK is referred to as the pacemaker of glycolysis. Our docking data indicate that DOX binds to the amino acid residue ARG 292, which is located in the enzyme's substrate binding site. In mice, genetic ablation of PFK resulted in increased glycogen accumulation in the heart muscles. Furthermore, $\mathrm{Pfkm}^{-/}$mice demonstrated a rise in heart weight along with cardiac hypertrophy. Additionally, left ventricular hypertrophy without interstitial fibrosis was seen in PFK deficient mice [33]. It is remarkable that DOX induces cardiac hypertrophy and left ventricular dysfunction [34], which exactly overlaps with that of $\mathrm{Pfkm}^{-/}$phenotype. Therefore, it is conceivable that DOX-induced cardiac defects are caused, at least in part, by PFK inactivation via binding to the substrate-binding site.

With enolase, DOX makes hydrophobic interactions at the residues SER 38, ARG 370, GLN 166, SER 368, LYS 392, ASP290, GLU 289, and ASP 245. There is a significant binding between DOX and ASP 245. ASP 245 is the binding site of $\mathrm{Mg}^{2+}$ (Figure 2). $\mathrm{Mg}^{2+}$ acts as a cofactor of the enzyme enolase. $\alpha$-enolase is a metalloenzyme that is catalytically active only when the magnesium $\left(\mathrm{Mg}^{2+}\right)$ ion is present. Enolase, also known as phosphopyruvate hydratase, is a metalloenzyme that catalyzes the conversion of 2-phosphoglycerate (2-PG) to phosphoenolpyruvate (PEP) in the ninth and concluding stage [35]. Upon pre-occupation with DOX, the enzyme would not engage with $\mathrm{Mg}^{2+}$ resulting in the non-functional enzyme. As a result, it is plausible that DOX inhibits an $\alpha$-enolase enzyme, preventing ATP production during glycolysis [36,37].

Thus, it is evident that the PFK and enolase are negatively affected by DOX. It is reasonable to speculate that glycolysis might not be complete and subsequent metabolic catastrophe resulting in the accumulation of glycolytic intermediates and reduced ATP. Our finding coincides with the earlier finding that $\alpha$-enolase plays a critical role in DOX-induced cardiomyocyte apoptosis and mitochondrial dysfunction [38].

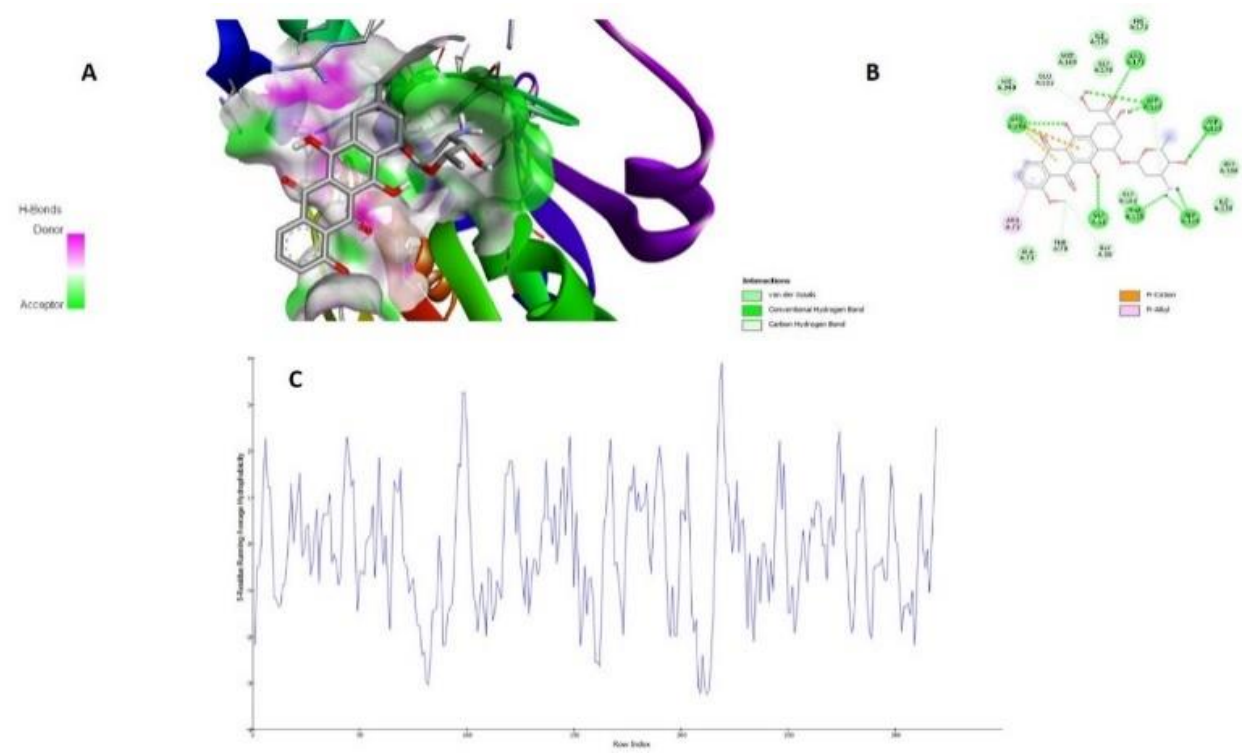

Figure 1. Interaction of DOX with Phosphofructokinase (PFK). A) Superimposition of DOX with PFK. B) the hydrogen bond between the DOX and PFK. C) Hydrophobicity plot of DOX with PFK. 


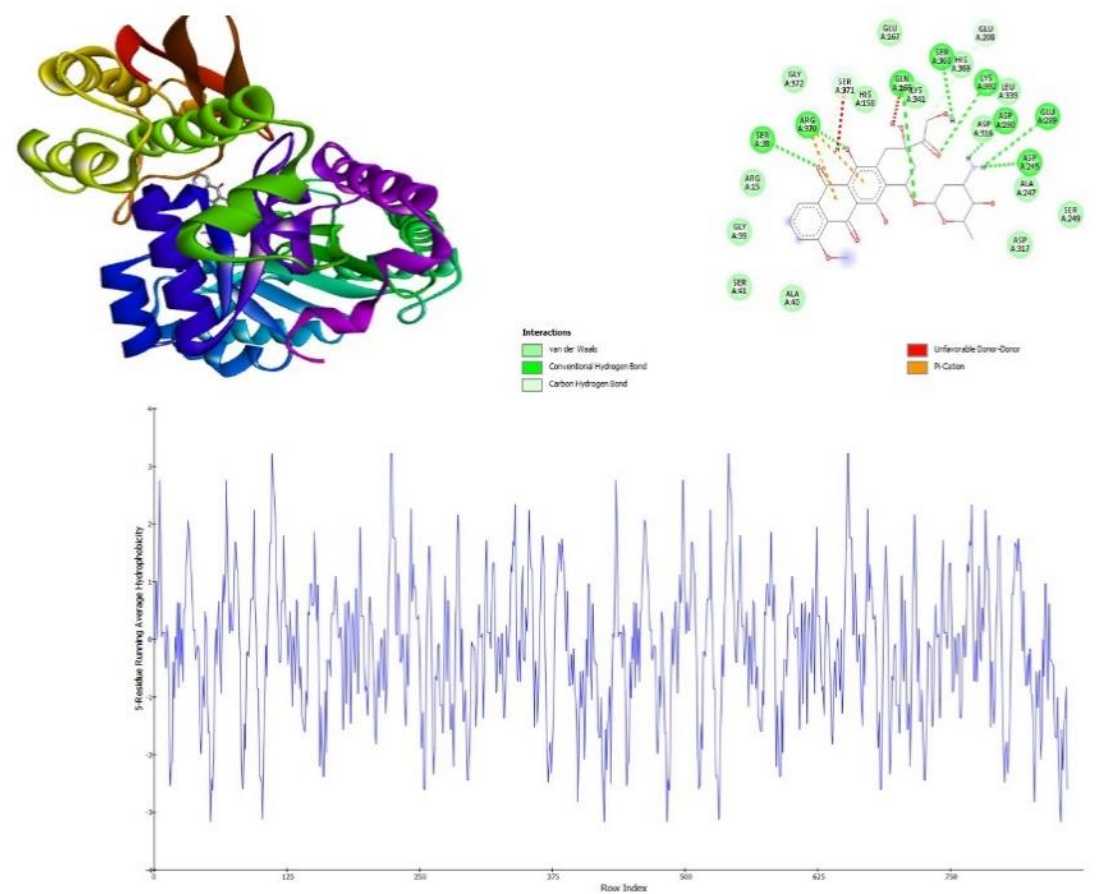

Figure 2. Interaction of DOX with Enolase. A) Superimposition of DOX with Enolase. B) the hydrogen bond between the DOX and Enolase. C) Hydrophobicity plot of DOX with Enolase.

Table 1. Comparison of Molecular Docking result of adriamycin with glycolytic enzymes.

\begin{tabular}{|c|c|c|c|c|c|c|c|c|c|c|}
\hline S.No & Gene Name & $\begin{array}{l}\text { Binding } \\
\text { Energy }\end{array}$ & $\begin{array}{l}\text { Ligand } \\
\text { Efficiency }\end{array}$ & $\begin{array}{l}\text { Inhibit } \\
\text { Constant }\end{array}$ & $\begin{array}{l}\text { Intermol } \\
\text { energy }\end{array}$ & $\begin{array}{c}\text { vdw hb } \\
\text { dissolve } \\
\text { energy }\end{array}$ & $\begin{array}{l}\text { Electrostatic } \\
\text { Energy }\end{array}$ & $\begin{array}{c}\text { Total } \\
\text { Internal }\end{array}$ & $\begin{array}{l}\text { Torsinol } \\
\text { Energy }\end{array}$ & $\begin{array}{l}\text { Unbound } \\
\text { Energy }\end{array}$ \\
\hline 1 & Hexokinase & -7.13 & -0.18 & 5.91 & -10.41 & -8.49 & -1.93 & -4.34 & 3.28 & -4.34 \\
\hline 2 & $\begin{array}{l}\text { Phosphofructose } \\
\text { Kinase }\end{array}$ & -8.74 & -0.22 & 394.01 & -12.02 & -8.79 & -3.23 & -3.34 & 3.28 & -3.34 \\
\hline 3 & Aldolase & -4.52 & -0.12 & 489.66 & -7.8 & -7.64 & -0.16 & -3.16 & 3.28 & -3.16 \\
\hline 4 & $\begin{array}{l}\text { Triose Phospho } \\
\text { isomerase }\end{array}$ & 255.96 & 6.56 & & 252.67 & 251.81 & 0.86 & -2.36 & 3.28 & -2.36 \\
\hline 5 & $\begin{array}{l}\text { Glyceraldehyde } 3 \\
\text { Phospho } \\
\text { dehydrogenase }\end{array}$ & -10.3 & -0.23 & 28.41 & -13.58 & -9.82 & -3.75 & -4.16 & 3.28 & -4.16 \\
\hline 6 & $\begin{array}{l}1 \text { Phosphoglycerate } \\
\text { Kinase }\end{array}$ & -5.91 & 0.15 & 46.83 & -9.19 & -8.21 & -0.98 & -4.58 & 3.28 & -4.58 \\
\hline 7 & $\begin{array}{l}2 \text { Phosphoglycerate } \\
\text { kinase }\end{array}$ & -5.91 & -0.15 & 46.83 & -9.19 & -8.21 & -0.98 & -4.58 & 3.28 & -4.58 \\
\hline 8 & $\begin{array}{l}\text { Phosphoglycerate } \\
\text { mutase }\end{array}$ & 1.25 & 0.03 & - & -2.03 & -1.82 & -0.21 & 10.25 & 3.28 & 10.25 \\
\hline 9 & Enolase & -5.11 & -0.13 & 178.88 & -8.39 & -7.56 & -0.83 & -4.13 & 3.28 & -4.13 \\
\hline 10 & Pyruvate Kinase & 4.36 & 0.11 & - & 1.1 & 1.27 & -0.18 & -0.88 & 3.28 & -0.88 \\
\hline
\end{tabular}

Table 2. Docking calculation depicting interacting residues, binding site residues ad atoms involved in $\mathrm{H}-$ bonding along with interacting residues common to reported active binding site residues.

\begin{tabular}{|c|c|c|c|c|}
\hline S.No & Protein & Protein-Ligand Binding Site & Hydrogen Bond & Active Site \\
\hline 1 & Hexokinase & $\begin{array}{l}\text { PHE } 67 \text {, ARG 69, LEU 797, CYS 813, ILE } 817 \text {, } \\
\text { ASP 814, THR 161, VAL 68, LEU 168, LEU 463, } \\
\text { LYS 162, ALA 460, ILE 203, ASP 164, ALA } 464 .\end{array}$ & $\begin{array}{l}\text { PHE 67, ARG 69, ASP 814, ALA } \\
460 .\end{array}$ & NIL \\
\hline 2 & Phosphofructokinase & $\begin{array}{l}\text { GLY 10, THR 70, ALA 71, ARG 72, ARG 292, } \\
\text { HIS 249, GLU 222, MET 169, GLY 170, , ARG } \\
\text { 171, HIS 172, ILE 126, ASP 127, ASP 103, GLY } \\
\text { 104, ILE 130, ASP 129, THR 125, GLY 102, } \\
\text { GLY } 11\end{array}$ & $\begin{array}{l}\text { GLY 11, THR 125, ASP 129, ASP } \\
\text { 103, ASP 127, ARG 171, ARG } 292 .\end{array}$ & $\begin{array}{l}\text { ARG } 292 \\
\text { (Substrate } \\
\text { binding site) }\end{array}$ \\
\hline 3 & Aldolase & $\begin{array}{l}\text { ASP 144, GLU 174, GLY 227, HIS 226, UNK 0, } \\
\text { HIS 226, GLN 59, ASP 109, ASN 286, GLY 265, } \\
\text { ASN 35, THR 289, ASP 288, GLN 292, SER 61, } \\
\text { GLY 63, ASN 62, LEU 115, HIS 110, ALA } 112 .\end{array}$ & ASP 288, ASN 286, ASP 109 & Nil \\
\hline 4 & $\begin{array}{l}\text { Triose Phospho } \\
\text { isomerase }\end{array}$ & $\begin{array}{l}\text { VAL 92, ALA 63, TRP 12, ILE 124, VAL 40, } \\
\text { ALA 10, VAL 41, ALA 42, ALA 9, VAL 233, } \\
\text { GLY 234, LYS 13, GLY 211, SER 213, GLY 212, } \\
\text { VAL 169, ILE 172, GLU 167, SER 96, HIS 95, } \\
\text { LEU 232, ASN 11, ARG 98, GLN 65, ASN 66, } \\
\text { LEU 93, GLY 94. }\end{array}$ & GLN 65, ALA 42, ALA 9, & Nil \\
\hline & \multicolumn{3}{|c|}{ https://biointerfaceresearch.com/ } & 531 \\
\hline
\end{tabular}




\begin{tabular}{|c|c|c|c|c|}
\hline S.No & Protein & Protein-Ligand Binding Site & Hydrogen Bond & Active Site \\
\hline 5 & $\begin{array}{l}\text { Glyceraldehyde } 3 \\
\text { Phospho } \\
\text { dehydrogenase }\end{array}$ & $\begin{array}{l}\text { ASP } 185, \text { HIS 192, ARG 166, ARG 167, CYS } \\
\text { 139, GLN 300, ASP 170, ILE 12, GLU 301, THR } \\
\text { 11, THR 84, PRO 86, THR 85, GLU 110, GLN } \\
\text { 107, GLY 109, ASN 87, SER 138. }\end{array}$ & $\begin{array}{l}\text { ARG 167, ASP 170, THR 85, ASN } \\
87\end{array}$ & Nil \\
\hline 6 & $\begin{array}{l}1 \text { Phosphoglycerate } \\
\text { Kinase }\end{array}$ & $\begin{array}{l}\text { ARG 38, ASN 35, GLN 37, GLU 193, VAL 391, } \\
\text { THR 393, SER 392, GLY 371, SER 398, GLY } \\
\text { 372, GLY } 395\end{array}$ & $\begin{array}{l}\text { ARG 38, ASN 35, VAL 391, THR } \\
\text { 393, SER } 392 .\end{array}$ & Nil \\
\hline 7 & $\begin{array}{l}2 \text { Phosphoglycerate } \\
\text { kinase }\end{array}$ & $\begin{array}{l}\text { ARG 38, AASN 35, GLN 37, GLU 192, VAL } \\
\text { 391, THR 393, SER 392, GLY 371, SER 398, } \\
\text { GLY 372, GLY 395 }\end{array}$ & $\begin{array}{l}\text { ASN 35, ARG 38, SR 392, THR } \\
\text { 393, VAL 391. }\end{array}$ & Nil \\
\hline 8 & $\begin{array}{l}\text { Phosphoglycerate } \\
\text { mutase }\end{array}$ & $\begin{array}{l}\text { ASP 263, PHO 262, PHE 298, PHE 342, HIS 297, } \\
\text { SER 299, GGLU 349, GLN 267, GLU 300, ILE } \\
\text { 266, TRP 195, ASN 270, TYR 337, LEU 359, } \\
\text { THR 334, ASP 192, ARG 191, GLU 335, LYS } \\
\text { 193, PRO 338. }\end{array}$ & GLN 267, SER 299, & Nil \\
\hline 9 & Enolase & $\begin{array}{l}\text { ALA 40, SER 41, GLY 39, ARG 15, SER 38, } \\
\text { ARG 370, GLY 372, SER 371, HIS 158, GLN } \\
\text { 166, GLU 167, LYS 341, SER 368, HIS 369, LYS } \\
\text { 392, GLU 208, LEU 339, ASP 316, ASP 290, } \\
\text { GLU 289, ASP 245, ALA 247, SER } 249 \text { and ASP } \\
317\end{array}$ & $\begin{array}{l}\text { SER 38, ARG 370, GLN 166, SER } \\
\text { 368, LYS 392, ASP290, GLU 289, } \\
\text { ASP } 245\end{array}$ & $\begin{array}{l}\text { ASP 245 } \\
\left(\mathrm{Mg}^{2+}\right. \\
\text { Binding site) } \\
\text { HIS } 158 \\
\text { (Substrate } \\
\text { binding Site) }\end{array}$ \\
\hline 10 & Pyruvate Kinase & $\begin{array}{l}\text { ASP 354, PHE 26, LEU 33, HIS 29, ILE 389, } \\
\text { LEU 353, ALA 388, LYS 311, MET 30, PHE 26, } \\
\text { ASP 354, LEU 33, MET 30, HIS 29, ALA 388, } \\
\text { ILE 389, TYR 390, LEU 353, LYS } 311\end{array}$ & $\begin{array}{l}\text { Lys } 311 \text {, ALA 388, TYR 390, LEU } \\
353 \text {, }\end{array}$ & Nil \\
\hline
\end{tabular}

\subsection{Interaction of doxorubicin with enzymes involved in iron homeostasis.}

To improve the understanding of the interaction between the DOX and iron homeostasis-related proteins, we employed in silico molecular modeling. The best docking result is shown in Fig 3 and tables 3 and 4. The docking predicted the possible interaction of DOX with ferritin, HMOX1, IRP, and transferrin which are involved in maintaining iron homeostasis. Among these four, the binding with HMOX1 shows a significant binding. The binding free energy $\left(\Delta \mathrm{G}^{0}\right)$ was found to be $-6.56 \mathrm{KJmol}^{-1}$. A negative value of $\Delta \mathrm{G}^{0}$ implies that the binding reaction is thermodynamically favorable, and the value of binding constant predicts high binding affinity between protein and ligand (drug). In general, HMOX1/HO-1 protein is found in the cytosol studded with ER. Evidence suggests that HO-1 might get localized into mitochondria $[39,40]$. HO-1 makes a metabolic connection between oxidative phosphorylation (oxphos) and the heme group [41].

The validation of the binding mode was predicted, and the interacting amino acid residues is shown in Fig 3 and tables 3 and 4. From the docking analysis, DOX significantly interacts with the following amino acid residues of HMOX1: Tyr 134, Arg 183, Lys 18, Tyr 134, His 25. The binding between the DOX and HMOX1 makes a hydrophobic interaction with Tyr 134, Arg 136, Glu 29. These amino acid residues are the iron-binding sites in the enzyme. The docking study revealed the interaction of DOX with HMOX1, which might negatively affect the enzyme's ability to bind to iron. As a result, free iron is likely to accumulate. In mitochondria, heme mainly acts as a co-factor for mitochondrially encoded proteins involved electron transport chain (ETC) [42]. Moreover, the accumulation of free irons plays a critical role in DOX-induced cardiotoxicity [43].

In addition, free heme is an essential source of redox-active iron, which causes cellular damage [44]. Previous studies also revealed that the DOX could interact with iron directly to form a DOX-Fe complex, resulting in iron cycling between $\mathrm{Fe}(\mathrm{II})$ and $\mathrm{Fe}$ (III) forms and substantial ROS production [45-47]. Heme-driven generation of ROS is mostly involved in the pathophysiology of various disorders by causing damage in nucleic acids, proteins, and 
membrane lipids active in various cellular signaling pathways, alterations in protein expression, and upsetting membrane channels, amid other related toxic effects [48].

Table 3. Comparison of Molecular Docking result of adriamycin with proteins involved in iron homeostasis.

\begin{tabular}{|c|c|c|c|c|c|c|c|c|c|c|}
\hline S.No & Gene Name & $\begin{array}{l}\text { Binding } \\
\text { Energy }\end{array}$ & $\begin{array}{c}\text { Ligand } \\
\text { Efficiency }\end{array}$ & $\begin{array}{c}\text { Inhibit } \\
\text { Constant }\end{array}$ & $\begin{array}{c}\text { Intermol } \\
\text { energy }\end{array}$ & $\begin{array}{c}\text { vdw hb } \\
\text { dissolve energy }\end{array}$ & $\begin{array}{c}\text { Electrostatic } \\
\text { Energy }\end{array}$ & $\begin{array}{c}\text { Total } \\
\text { Internal }\end{array}$ & $\begin{array}{l}\text { Torsinol } \\
\text { Enerrgy }\end{array}$ & $\begin{array}{l}\text { Unboun } \\
\text { d Energy }\end{array}$ \\
\hline 1 & Ferritin & -7.01 & -0.18 & 7.28 & -10.29 & -7.94 & -2.35 & -4.03 & 3.23 & -4.03 \\
\hline 2 & HOMX1 & -6.56 & -0.17 & 15.45 & -9.84 & -8.62 & -1.22 & -4.54 & 3.28 & -4.54 \\
\hline 4 & Transferin & -9.31 & -0.24 & 150.52 & -12.59 & -9.68 & -2.91 & -4.18 & 3.28 & -4.18 \\
\hline
\end{tabular}

Table 4. Docking calculation depicting interacting residues, binding site residues, and atoms involved in $\mathrm{H}-$ bonding along with interacting residues common to reported active binding site residues (Iron homeostasis

\begin{tabular}{|c|c|c|c|c|}
\hline S.NO & Protein & Interacted Residues & $\begin{array}{l}\text { Ligand and Protein } \\
\text { atom involved in } \mathrm{H}- \\
\text { bonding }\end{array}$ & $\begin{array}{l}\text { Interacting residues } \\
\text { familiar with reported } \\
\text { active binding sites } \\
\end{array}$ \\
\hline 1 & Ferritin & $\begin{array}{l}\text { GLU 39, TYR 36, ASP 42, ASP 41, ARG 40, GLY } \\
\text { 148, VAL 141, ILE 144, LYS } 145\end{array}$ & $\begin{array}{l}\text { ASP 41, ASP 42, GLU } \\
39\end{array}$ & Nil \\
\hline 2 & HOMX1 & $\begin{array}{c}\text { ARG 136, GLU 29, GLN 38, MET 34, LEU 147, } \\
\text { GLY 143, GLY 139, GLY 144, SER 142, LYS } \\
\text { 179, ARG 183, LYS 18, TYR 134, HIS 25, PHE } \\
\text { 207, ASN 210, THR 135, PHE 214, ALA 28, ARG } \\
136,\end{array}$ & $\begin{array}{l}\text { TYR 134, ARG 136, } \\
\text { GLU } 29\end{array}$ & $\begin{array}{l}\text { Tyr 134, Arg 183, Lys } \\
\text { 18, Tyr 134, His } 25 \text { (Iron } \\
\text { binding Site). }\end{array}$ \\
\hline 3 & IRP1 & $\begin{array}{c}\text { ASP 678, ARG 541, SER 778, GLY 777, ALA } \\
\text { 683, PHE 88, ARG 713, THR 89, GLN 86, SER } \\
\text { 779, THR 204, HIS 126, SER 206, ASP 205, HIS } \\
\text { 207, ILE 177, HIS 178, CYS 437, SER 436, ILE } \\
\text { 176, CYS 503, CYS 506, ILE 507, ARG 536, ARG } \\
\text { 780 }\end{array}$ & $\begin{array}{l}\text { HIS } 207, \text { ASP } 205 \text {, } \\
\text { SER 206, HIS } 126, \\
\text { CYS 506, ASP } 678, \\
\text { SER } 778\end{array}$ & Nil \\
\hline 4 & Transferin & $\begin{array}{c}\text { ASP 560, SER 492, ASN 493, THR 518, GLN 520, } \\
\text { GLN 524, LEU 522, TYR 523, ASP 525, MET } \\
\text { 510, VAL 496, TRP 528, VAL 532, LYS 495, PHE } \\
\text { 494, ASP 360, THR } 286\end{array}$ & $\begin{array}{l}\text { ASP 560, ASN 493, } \\
\text { THR 518, GLN 520, } \\
\text { LEU } 522\end{array}$ & Nil \\
\hline
\end{tabular}
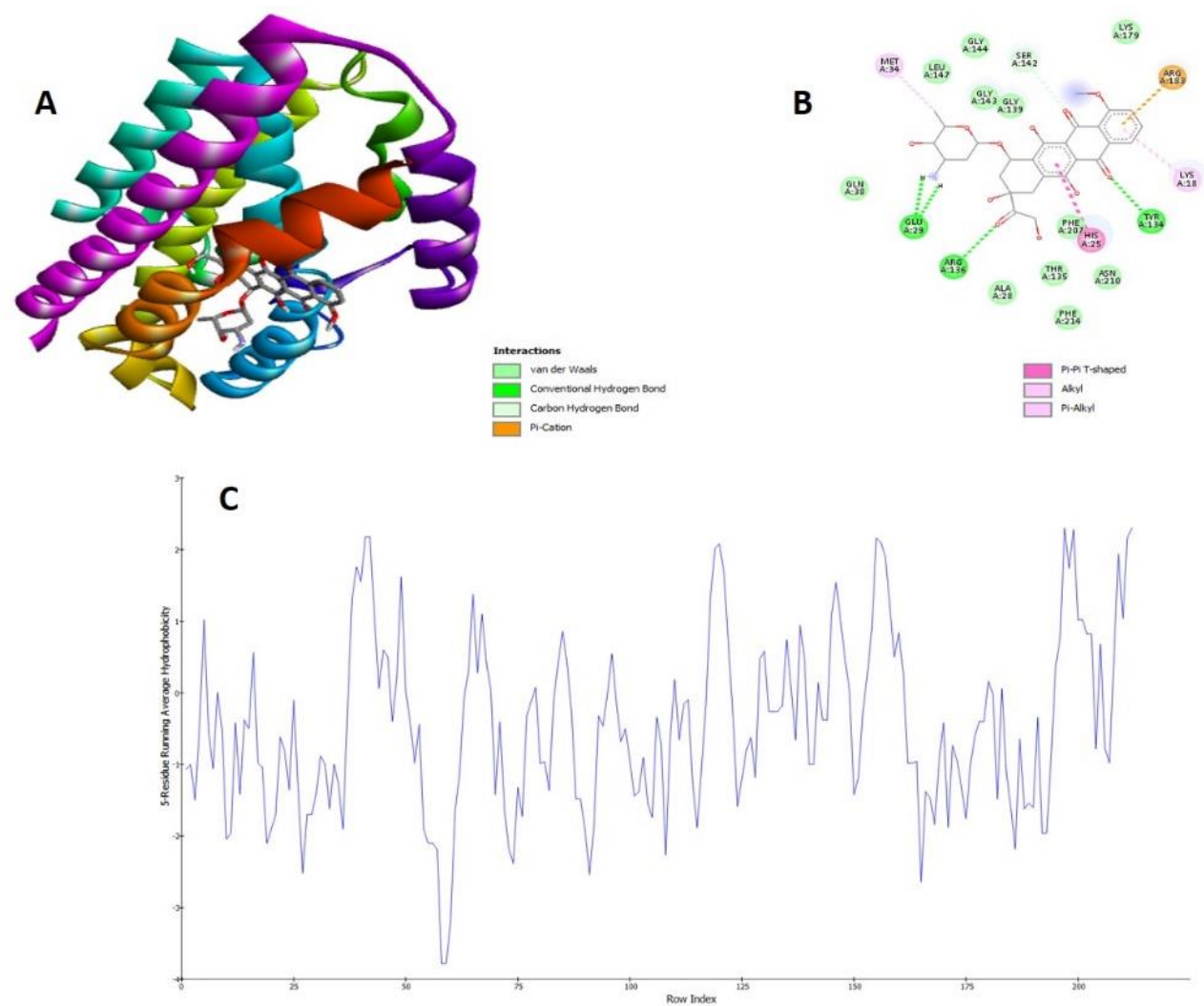

Figure 3. Interaction of DOX with Heme-oxygenase-1(HMOX1). A) Superimposition of DOX with HMOX1. B) the hydrogen bond between the DOX and HMOX1. C) Hydrophobicity plot of DOX with HMOX1. 
3.3. Interaction of doxorubicin with enzymes involved in the Krebs cycle.

Further, we evaluated the interaction of doxorubicin with enzymes involved in Kreb's cycle (aconitase, alpha dehydrogenase, citrate synthase, fumarase, isocitrate dehydrogenase, malate dehydrogenase, and succinate dehydrogenase) by molecular docking (Figure 4 and Table 5 and 6). To our surprise, DOX did not significantly interact with any of the enzymes above. Succinate dehydrogenase interacted with doxorubicin with the highest binding energy $\left(-7.17 \mathrm{KJmol}^{-1}\right)$, followed by isocitrate dehydrogenase $\left(-6.31 \mathrm{KJmol}^{-1}\right)$ and malate dehydrogenase $\left(-5.71 \mathrm{KJmol}^{-1}\right)$, which have a more hydrophobic interaction with DOX. However, DOX does not bind to the active site of any of these enzymes. This reveals that the DOX does not directly inhibit or alter the Krebs cycle function. However, doxorubicin might affect Kreb's cycle by disrupting iron homeostasis.

As already shown, the activity of HMOX1/HO-1 is affected due to its binding with DOX (Section 3.2). Inhibiting HO-1 raises mitochondrial heme content [39]. Depletion of iron in the mitochondria might negatively affect the enzyme succinate dehydrogenase (SDH) [25]. The abrogation of HMOX1 disrupts the ETC and TCA cycle, resulting in a decreased oxidative phosphorylation (oxphos), through disruption of succinate dehydrogenase (SDH). Subsequently, the excessive heme group results from a lack of active HO-1, which leads to the accumulation of succinate. The dysfunction of HMOX1 has been shown to raise the mitochondrial heme content [39]. Indeed, the higher the succinate level, the higher the membrane potential and the slower the flow of electrons, limiting ADP. [49]. Once the heme level is increased, fumarate is incorporated with succinyl CoA via succinate, thus it reversing these intermediate of TCA cycle [41].

Table 5. Comparison of Molecular Docking result of adriamycin with enzymes involved in Krebs cycle.

\begin{tabular}{|c|c|c|c|c|c|c|c|c|c|c|}
\hline S.No & Gene Name & $\begin{array}{l}\text { Binding } \\
\text { Energy }\end{array}$ & $\begin{array}{c}\text { Ligand } \\
\text { Efficiency }\end{array}$ & $\begin{array}{c}\text { Inhibit } \\
\text { Constan } \\
\mathbf{t} \\
\end{array}$ & $\begin{array}{l}\text { Intermol } \\
\text { energy }\end{array}$ & $\begin{array}{l}\text { vdw hb } \\
\text { dissolve } \\
\text { energy }\end{array}$ & $\begin{array}{l}\text { Electrostati } \\
\text { c Energy }\end{array}$ & $\begin{array}{c}\text { Total } \\
\text { Internal }\end{array}$ & $\begin{array}{l}\text { Torsinol } \\
\text { Energy }\end{array}$ & $\begin{array}{l}\text { Unbound } \\
\text { Energy }\end{array}$ \\
\hline 1 & Aconitase & 28.45 & 0.73 & - & 25.17 & 25.44 & -0.27 & 9.35 & 3.28 & 9.35 \\
\hline 3 & Citrate Synthase & -5.18 & -0.13 & 159.28 & -8.46 & -7.47 & -0.99 & -4.37 & 3.28 & -4.37 \\
\hline 4 & Fumarase & -4.71 & -0.12 & 354.49 & -7.99 & -6.52 & -1.46 & -4.73 & 3.28 & -4.73 \\
\hline 5 & $\begin{array}{c}\text { Isocitrate } \\
\text { Dehydrogenase }\end{array}$ & -6.31 & -0.16 & 23.7 & -9.59 & -7.79 & -1.8 & -4.35 & 3.28 & -4.35 \\
\hline 6 & $\begin{array}{c}\text { Malate } \\
\text { Dehbydrogenas } \\
\mathrm{e}\end{array}$ & -5.71 & -0.15 & 65.29 & -8.99 & -8.36 & -0.64 & -4.74 & 3.28 & -4.74 \\
\hline 7 & $\begin{array}{c}\text { Succinate } \\
\text { Dehydrogenase }\end{array}$ & -7.17 & -0.18 & 5.58 & -10.45 & -10.41 & -0.04 & -4.59 & 3.28 & -4.59 \\
\hline
\end{tabular}

Table 6. Docking calculation depicting interacting residues, binding site residues, and atoms involved in $\mathrm{H}$ bonding along with interacting residues common to reported active binding site residues (TCA enzymes).

\begin{tabular}{|c|c|c|c|c|}
\hline S.No & Protein & Interacted Residues & $\begin{array}{l}\text { Ligand and Protein } \\
\text { atom involved in } \mathrm{H} \text { - } \\
\text { bonding }\end{array}$ & $\begin{array}{l}\text { Interacting residues } \\
\text { familiar with reported } \\
\text { active binding sites }\end{array}$ \\
\hline 1 & Aconitase & $\begin{array}{l}\text { ASN 446, TYR 445, ARG 447, ARG 452, HIS 167, SER } \\
\text { 166, ASP 165, ARG 644, SER 643, ALA 642, THR 164, } \\
\text { THR 75, ARG 580, GLN 72, ALA 74, ILE 425, ALA } \\
\text { 420, ILE 145, CYS 421, ASP 100, CYS 358, HIS 101, } \\
\text { SER 357, CYS 424, HIS 147, VAL 463, ILE } 146\end{array}$ & $\begin{array}{l}\text { ASN 446, HIS 167, } \\
\text { CYS } 421\end{array}$ & 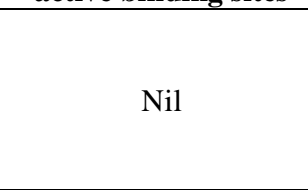 \\
\hline 2 & $\begin{array}{c}\text { Alpha } \\
\text { Dehydrogenase }\end{array}$ & $\begin{array}{l}\text { ASN 155, PHE 156, CYS 287, GLU 253, THR 230, PHE } \\
\text { 450, VAL 162, ASN 159, ILE 113, ARG 163, GLU 106, } \\
\text { PRO 444, VAL 105, SER 109, ARG 281, ALA 278, PRO } \\
\text { 441, ALA 442, ILE 288, GLN 160, VAL 286 }\end{array}$ & $\begin{array}{l}\text { CYS } 287, \text { GLU 253, } \\
\text { ASN 159, ARG } 163 \text {, } \\
\text { SER } 109 .\end{array}$ & Nil \\
\hline 3 & Citrate Synthase & $\begin{array}{c}\text { HIS 301, LEU 300, PRO 299, ALA 304, ARG 356, LEU } \\
\text { 303, ARG 428, ASP 402, VAL 401, HIS 262, PHE 424, } \\
\text { HIS 265, LEU 85, HIS 347, GLU 266, GLY 268, } \\
\text { ASN269, VAL270 }\end{array}$ & $\begin{array}{l}\text { HIS } 301, \text { PRO } 299, \\
\text { ALA 304, LEU 303, } \\
\text { ASP } 402 .\end{array}$ & Nil \\
\hline
\end{tabular}




\begin{tabular}{|c|c|c|c|c|}
\hline S.No & Protein & Interacted Residues & $\begin{array}{l}\text { Ligand and Protein } \\
\text { atom involved in } \mathrm{H}- \\
\text { bonding }\end{array}$ & $\begin{array}{l}\text { Interacting residues } \\
\text { familiar with reported } \\
\text { active binding sites }\end{array}$ \\
\hline 4 & Fumarase & $\begin{array}{l}\text { ASP 378, GLU 381, HIS 386, SER 382, GLY 379, PHE } \\
\text { 383, GLN 329, LEU 333, ALA 332, LEU 336, LEU 375, } \\
\text { ARG 374. }\end{array}$ & $\begin{array}{l}\text { ASP } 378, \text { GLU 381, } \\
\text { GLN } 329 .\end{array}$ & Nil \\
\hline 5 & $\begin{array}{l}\text { Isocitrate } \\
\text { Dehydrogenase }\end{array}$ & $\begin{array}{l}\text { VAL 276, HIS 309, ASP 279, LEU 288, ASP 275, ARG } \\
\text { 109, ALA 308, ARG 132, ARG 100, GLY 310, THR 311, } \\
\text { THR 75, ILE 76, THR 77. }\end{array}$ & $\begin{array}{l}\text { ASP } 279, \text { ARG } 109, \\
\text { ALA 308, THR 75, } \\
\text { THR } 77 .\end{array}$ & Nil \\
\hline 6 & $\begin{array}{c}\text { Malate } \\
\text { Dehbydrogenase }\end{array}$ & $\begin{array}{c}\text { ILE 12, GLY 11, THR 224, GLN 14, LEU 225, ALA 15, } \\
\text { THR 224, GLY 220, GLY 221, GLN 14, SER222, LYS } \\
\text { 217, VAL 38, ALA 9, GLY } 10\end{array}$ & $\begin{array}{l}\text { GLN 14, GLY 220, LYS } \\
221 .\end{array}$ & Nil \\
\hline 7 & $\begin{array}{l}\text { Succinate } \\
\text { Dehydrogenase }\end{array}$ & $\begin{array}{l}\text { ALA 201, GLY 14, GLY 16, ALA 15, THR 202, LYS 38, } \\
\text { ILE 217, VAL 39, SER 54, ARG 43, SER 44, GLY 203, } \\
\text { ASN 218, GLY 204, GLY 388, ASN 214, MET 356, HIS } \\
\text { 354, HIS 45, ARG 399, TYR 355, SER 404, THR 46, } \\
\text { LEU 405, LEU 408, GLY 17, ALA 18, GLY } 19\end{array}$ & $\begin{array}{l}\text { ALA 201, THR 46, } \\
\text { ASN 218, ARG } 43\end{array}$ & Nil \\
\hline
\end{tabular}

Thus, it is possible to speculate that the dysfunction of HMOX-1 leads to the accumulation of succinate and succinyl-CoA. The TCA cycle is the key source of mitochondrial NADH. When NADH is depleted, SDH activity reduces, as indicated when Oxphos is reduced [50,51]. This difference may justify additional investigation utilizing metabolomics to better understand the alterations in TCA cycle due to DOX. Thus, we speculate that the dysfunction of HMOX1 by DOX alters the function of TCA cycle causes a reduced level of ATP production.

\subsection{Interaction of Doxorubicin with enzymes involved in ETC.}

Cardiolipin (CL) is a central player for several mitochondrial bioenergetic processes $[52,53]$. CL, a specific phospholipid which mainly localized in the inner mitochondrial membrane (IMM) and is synthesized in IMM. CL is required to activate several inner mitochondrial membrane proteins such as enzyme complexes of ETC and, subsequently, the production of ATP [54]. Cardiolipin is essential for the activation of certain enzymes involved in the electron transport chain, which are complex IV (cytochrome oxidase), complex I (NADH-ubiquinone oxidoreductase), and Complex III (ubiquinone-cytochrome oxidoreductase) $[17,53]$. DOX significantly binds with cardiolipin, and its binding energy is $6.07 \mathrm{KJmol}^{-1}$. DOX makes hydrophobic interaction with cardiolipin at the Lys 216, Asp 236, Gln 29, Tyr 63. Tyr 63 is the site for C3H1-type, a zinc finger factor site (Figure 4 and Table 7 and 8). It indicates that cardiolipin is a direct target of DOX, and it inhibits the transcription process. The binding of DOX with cardiolipin causes the inactivation of complex I-III [55]. Previous studies also revealed that the DOX has a high affinity with CL which renders the oxphos mechanism [56]. Moreover, cardiolipin deficiency releases a higher level of cytochrome in IMM and triggers apoptosis [57]. Modification in the CL profile could be responsible for the changes in the bioenergetics parameters, such as reduced level of $\mathrm{O}_{2}$ consumption, dysfunction of complexes I, III, and IV [58], where mitochondria act as a prime source of ATP synthesis through the ETC and Oxphos. But a defect in cardiolipin correlated with alteration of ETC complexes and resulted in energy deficit [54].

For PINK1 (Phosphatase and Tensin homolog-induced kinase 1), DOX has a binding energy of $-6.36 \mathrm{KJmol}^{-1}$. With PINK1, DOX makes hydrophobic interactions at amino acid residues Asp 229, Cys 362, Lys 339, Asn 231, Asn 227, where Cys 362 acts as a proton acceptor. Mutations in PINK1 or silencing of PINK1 result in impaired mitochondrial function, including a reduced membrane potential $(\Delta \Psi \mathrm{m})$ and impaired oxidative phosphorylation, 
excessive vulnerability to raised mitochondrial calcium, reduced mtDNA copy number, and increased free radical generation [59-61]. The impairment/loss of PINK1 increases the heart's risk of ischemia-reperfusion injury, which may be due to impaired mitochondrial activity [62]. Thus, the interaction between the DOX with PINK1 might affect the membrane potential. The impaired membrane potential causes mitochondrial toxicity. Doxorubicin dysregulates the PINK1/parkin pathway, inducing mitophagy and mitochondrial damage [63].

On the other hand, ubiquitin (CoQ), controlled by PINK 1 [64], controls ROS generation in the ETC. When ubiquitin loses its function, reactive oxygen species (ROS) generation rises. The increased ROS production negatively affects the RYR2 that activates the $\mathrm{Ca}^{2+}$ ions to leak and causes the accumulation of $\mathrm{Ca}^{2+}$ ions. Altered activity of RYR2 and irregular $\mathrm{SR} \mathrm{Ca}^{2+}$ release causes various implications triggering arrhythmogenesis, cardiomyopathy, and heart failure [65].

Depletion of PINK1 results in a moderate fragmentation of the mitochondrial matrix, depolarization of the mitochondrial membrane, which increases the reactive oxygen species. This leads to decreased $\mathrm{Ca}^{2+}$ absorption by mitochondria following physiological stimulation. As a result, cells lacking PINK1 exhibit inadequate mitochondrial ATP production, which is worsened during times of high ATP demand, impairing cytosolic $\mathrm{Ca}^{2+}$ extrusion [66]. Thus, the significant binding of cardiolipin and PINK1 leads to the elevation of oxidative stress, which increases ROS generation. Therefore, the interaction of DOX with PINK1 is directly related to the accumulation of $\mathrm{Ca}^{2+}$ ions in the mitochondria by activating $\mathrm{RYR}$. Changes in the $\mathrm{Ca}^{2+}$ level of the mitochondria negatively affect the membrane potential $(\Delta \psi)$ due to the deficiency in ATP synthesis.
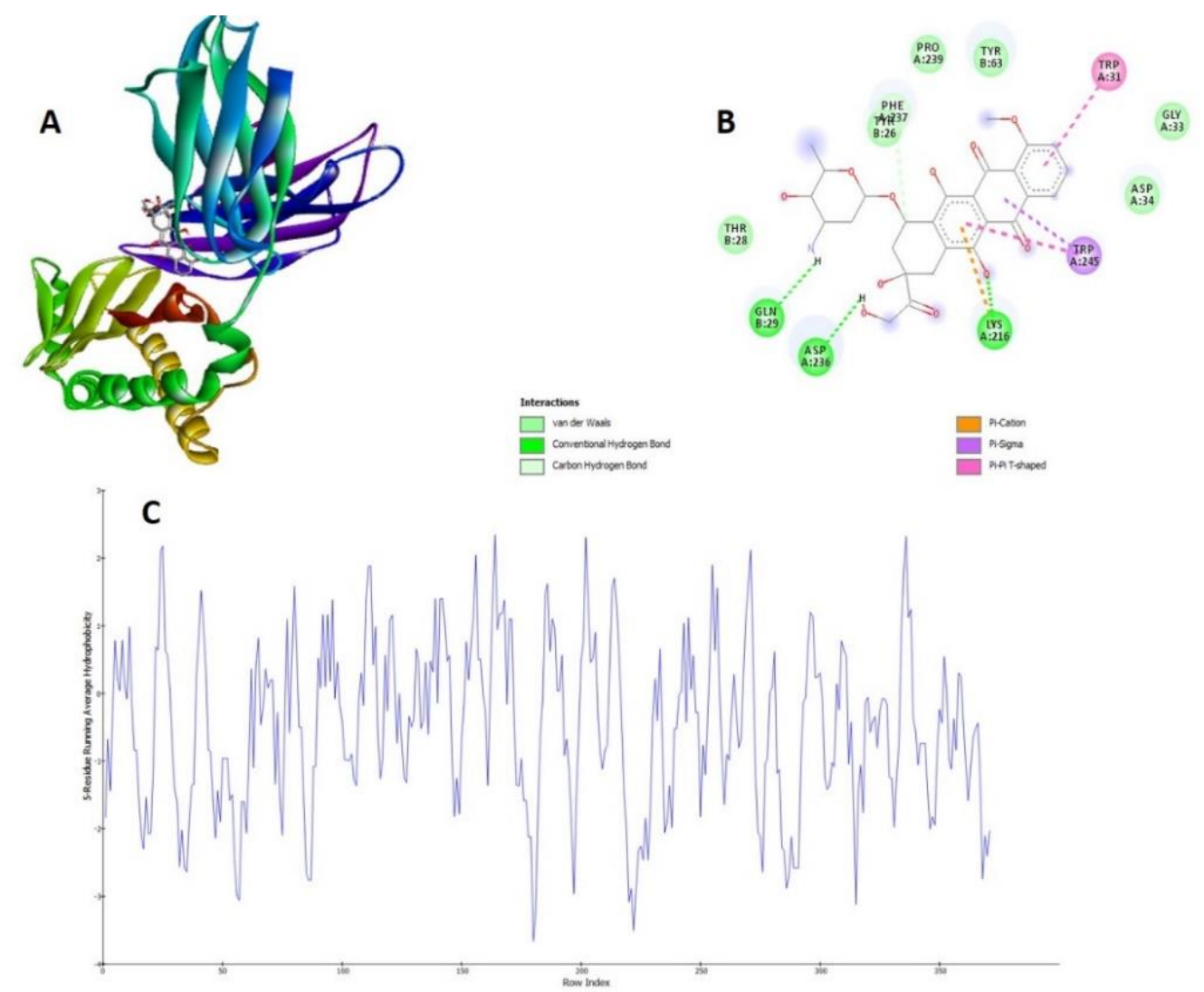

Figure 4. Interaction of DOX with Cardiolipin. A) Superimposition of DOX with Cardiolipin. B) the hydrogen bond between the DOX and Cardiolipin. C) Hydrophobicity plot of DOX with Cardiolipin. 

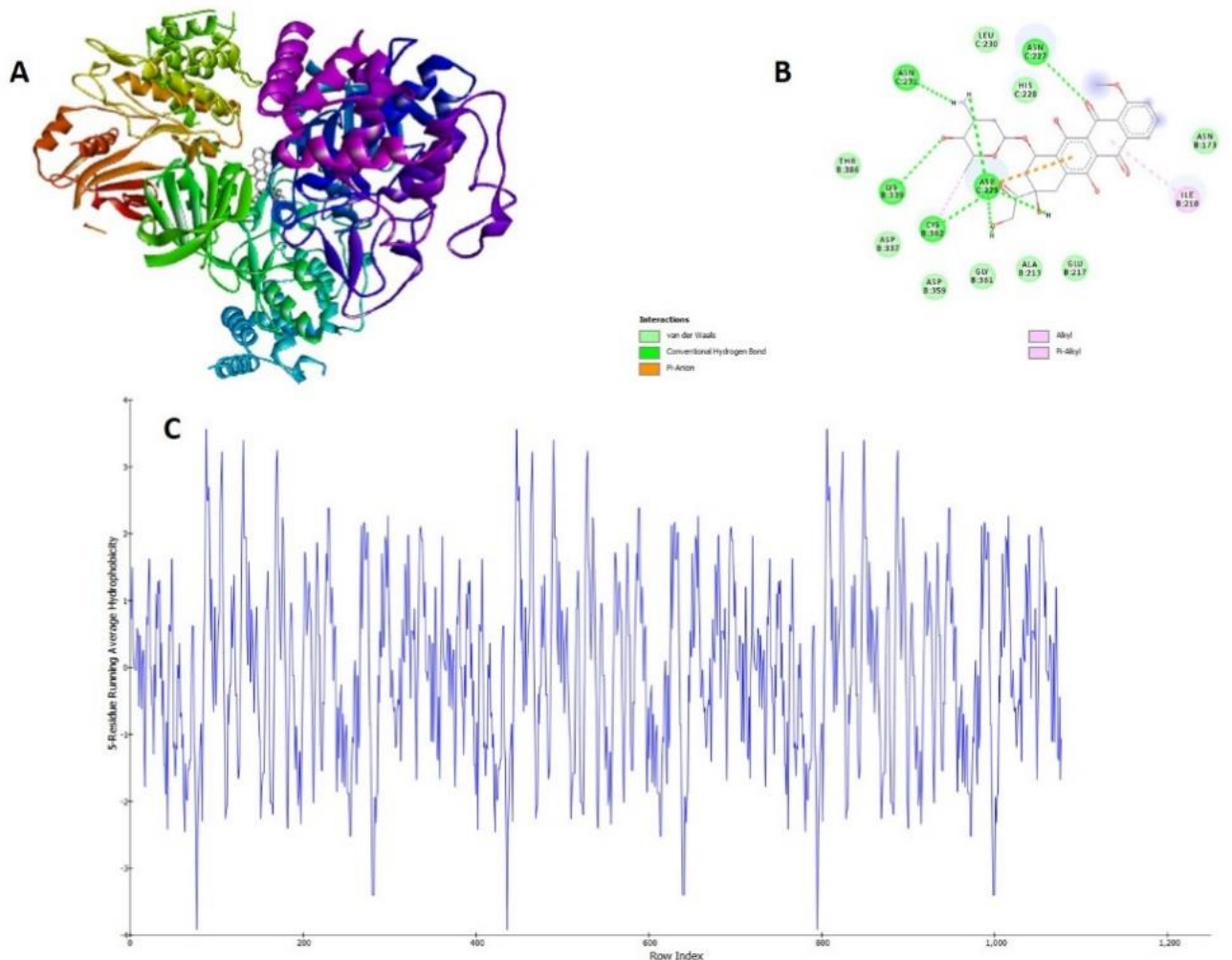

Figure 5. Interaction of DOX with PINK1. A) Superimposition of DOX with PINK1. B) the hydrogen bond between the DOX and PINK1. C) Hydrophobicity plot of DOX with PINK1.

Table 7. Comparison of Molecular Docking result of adriamycin with enzymes involved in ETC.

\begin{tabular}{|c|c|c|c|c|c|c|c|c|c|c|}
\hline S.No & Gene Name & $\begin{array}{l}\text { Binding } \\
\text { Energy }\end{array}$ & $\begin{array}{c}\text { Ligand } \\
\text { Efficiency }\end{array}$ & $\begin{array}{c}\text { Inhibit } \\
\text { Constant }\end{array}$ & $\begin{array}{l}\text { Intermol } \\
\text { energy }\end{array}$ & $\begin{array}{c}\text { vdw hb } \\
\text { dissolve } \\
\text { energy }\end{array}$ & $\begin{array}{c}\text { Electrostatic } \\
\text { Energy }\end{array}$ & $\begin{array}{c}\text { Total } \\
\text { Internal }\end{array}$ & $\begin{array}{c}\text { Torsinol } \\
\text { Energy }\end{array}$ & $\begin{array}{c}\text { Unbound } \\
\text { Energy }\end{array}$ \\
\hline 1 & Cardiolipin & -6.07 & -0.16 & 35.44 & -9.35 & -8.52 & -0.83 & -5.99 & 3.28 & -5.99 \\
\hline 2 & PINK1 & -6.36 & -0.16 & 21.69 & -9.64 & -8.38 & -1.26 & -4.61 & 3.28 & -4.61 \\
\hline 3 & Ubiquitin & 54.95 & 1.41 & -- & 51.67 & 52.28 & -0.61 & -1.91 & 3.28 & -1.91 \\
\hline
\end{tabular}

Table 8. Docking calculation depicting interacting residues, binding site residues, and atoms involved in $\mathrm{H}-$ bonding along with interacting residues common to reported active binding site residues (ETC).

\begin{tabular}{|c|c|c|c|c|}
\hline S.No & Protein & Interacted Residues & $\begin{array}{l}\text { Ligand and Protein } \\
\text { atom involved in } \mathrm{H}- \\
\text { bonding }\end{array}$ & $\begin{array}{l}\text { Interacting residues } \\
\text { familiar with reported } \\
\text { active binding sites }\end{array}$ \\
\hline 1 & Cardiolipin & $\begin{array}{l}\text { LYS 216, ASP 236, GLN 29, THR 28, TYR 26, PHE } \\
\text { 237, PRO 239, TYR 63, TRP 31, GLY 33, ASP 34, } \\
\text { TRP 245, }\end{array}$ & $\begin{array}{c}\text { LYS 216, ASP 236, GLN } \\
29,\end{array}$ & $\begin{array}{l}\text { C3H1-type; } \\
\text { atypical Tyr } 63\end{array}$ \\
\hline 2 & PINK1 & $\begin{array}{l}\text { GLU 217, ALA 213, GLY 361, ASP 359, CYS } 362, \\
\text { ASP 337, LYS 339, THR 386, ASP 229, ASN 231, } \\
\text { HIS 228, LEU 230, ASN 227, ASN 173, ILE } 210\end{array}$ & $\begin{array}{l}\text { ASP 229, CYS 362, LYS } \\
339, \text { ASN 231, ASN } 227\end{array}$ & $\begin{array}{r}\text { Cys } 362 \\
\text { (Proton acceptor }\end{array}$ \\
\hline 3 & Ubiquitin & $\begin{array}{l}\text { LYS 577, LEU 534, ARG 442, ILE 578, GLN 443, } \\
\text { GLN 575, HIS 446, LEU 538, THR 571, GLN 570, } \\
\text { ARG 549, GLY 567, LEU 541, HIS 574, PRO 539 }\end{array}$ & GLN 443, ARG 442 & Nil \\
\hline
\end{tabular}

\subsection{Interaction of doxorubicin with enzymes involved in calcium homeostasis.}

Mitochondrial calcium is necessary for the TCA cycle mitochondrial matrix dehydrogenases to function properly [67]. Mitochondrial calcium is obtained mostly from the ER via the IP3R channel [68]. Calcium regulator genes IP3R, Seipin, SERCA, RYR, RYR2, troponin, VGCC, phospholamban, and CAMKII were docked with DOX. From the docking analysis, DOX significantly bind with RYR2 and CAMKII, and its binding energy is $6.39 \mathrm{KJmol}^{-1}$ and $-7.27 \mathrm{KJmol}^{-1}$. In the calcium ion channel, the DOX interacts with RYR2 at the amino acid residues Glu11, Glu 84, Glu 14, and with CAMKII, the DOX interacts at Lys 
268 Glu 163 (Table 9 and 10). Previous studies reported that the DOX binding target of RYR2 promotes a disturbance in $\mathrm{Ca}^{2+}$ homeostasis $[69,70]$. During diastole, it causes a reduction in $\mathrm{SR} \mathrm{Ca}^{2+}$ concentration and an elevation in cytoplasmic $\mathrm{Ca}^{2+}$ [71]. In addition, calcium/calmodulin-dependent protein kinase 2 (CAMK II) plays a role in calcium signaling. A change in CAMK II signaling was detected during the pathological condition. Similarly, a defect in CAMKII results in doxorubicin-induced cardiomyopathy [72].

Altered expression of the regulator genes for the exchange of calcium has been reported in DOX-induced cardiomyopathy in rabbits, including RYR2, Sarco/endoplasmic reticulum ATPase (SERCA2a), phospholamban, and calcium-storage genes [73,74], which is in agreement with our findings. The binding objective of DOX is to reduce the risk of $\mathrm{Ca}^{2+}$ homeostasis by RYR2 [69,70]. The $\mathrm{Ca}^{2+}$ in SR is lowered, and the cytoplasmic $\mathrm{Ca}^{2+}$ is increased throughout the diastolic period [71]. Thus, the binding target of DOX with RYR2 and CAMKII alters the function of calcium homeostasis, which alters the TCA and ETC cycle, leading to insufficient ATP production.

Table 9. Comparison of Molecular Docking result of adriamycin with calcium receptors.

\begin{tabular}{|c|c|c|c|c|c|c|c|c|c|c|}
\hline S.No & Gene Name & $\begin{array}{l}\text { Binding } \\
\text { Energy }\end{array}$ & $\begin{array}{c}\text { Ligand } \\
\text { Efficiency }\end{array}$ & $\begin{array}{c}\text { Inhibit } \\
\text { Constant }\end{array}$ & $\begin{array}{l}\text { Intermo } \\
\text { l energy }\end{array}$ & $\begin{array}{c}\text { vdw hb } \\
\text { dissolve } \\
\text { energy }\end{array}$ & $\begin{array}{c}\text { Electrostati } \\
\text { c Energy }\end{array}$ & $\begin{array}{c}\text { Total } \\
\text { Internal }\end{array}$ & $\begin{array}{c}\text { Torsinol } \\
\text { Energy }\end{array}$ & $\begin{array}{c}\text { Unbound } \\
\text { Energy }\end{array}$ \\
\hline 1 & IP3R & -6.41 & -0.16 & 19.95 & -9.69 & -8.43 & -1.26 & -4.15 & 3.28 & -4.15 \\
\hline 2 & RYR & -9.38 & -0.24 & 132.43 & -12.66 & -9.8 & -2.86 & -3.84 & 3.28 & -3.84 \\
\hline 3 & SERCA & -9.28 & -0.24 & 162.16 & -12.54 & -10.64 & -1.9 & -2.87 & 3.28 & -2.87 \\
\hline 4 & SEIPIN & 429.66 & 11.02 & - & 426.38 & 426.66 & -0.27 & 14.17 & 3.28 & 14.17 \\
\hline 5 & CaMKII & -7.27 & -0.19 & -4.65 & -10.56 & -9.89 & -0.66 & -4.92 & 3.28 & -4.92 \\
\hline 6 & Phospholamban & -4.16 & -0.11 & 890.05 & -7.44 & -7.01 & -0.43 & -4.44 & -3.28 & -4.44 \\
\hline 7 & RYR2 & -6.39 & -0.16 & 20.54 & -9.68 & -6.31 & -3.37 & -3.82 & 3.28 & -3.82 \\
\hline 8 & VGCC & 106.65 & 2.73 & & 103.37 & 103.27 & 0.0 & -0.26 & 3.28 & -0.26 \\
\hline
\end{tabular}

Table 10. Docking calculation depicting interacting residues, binding site residues and atoms involved in $\mathrm{H}-$ bonding along with interacting residues common to reported active binding site residues (Calcium receptor).

\begin{tabular}{|c|c|c|c|c|}
\hline S.NO & Protein & Interacted Residues & $\begin{array}{l}\text { Ligand and Protein atom } \\
\text { involved in H-bonding }\end{array}$ & $\begin{array}{l}\text { Interacting residues } \\
\text { familiar with reported } \\
\text { active binding sites }\end{array}$ \\
\hline 1 & IP3R & $\begin{array}{l}\text { ASP 444, ASN 447, LEU 30, ASP 448, ASN 203, ALA 43, } \\
\text { SER 28, LYS } 42\end{array}$ & $\begin{array}{l}\text { ASN 203, ASP 444, ASN } \\
\text { 447, LEU } 30\end{array}$ & Nil \\
\hline 2 & RYR & $\begin{array}{l}\text { PRO 2671, ALA 2672, TYR 2743, LEU 2787, TYR 2621, } \\
\text { LYS 2783, SER 2625, LYS 2628, HIS 2626, ASP 2786, } \\
\text { LEU 2723, HIS 2624, TRP 2629, ILE 2667, TYR } 2668\end{array}$ & $\begin{array}{l}\text { TYR 2668, TYR 2621, SER } \\
\text { 2625, ASP } 2786 \\
\end{array}$ & Nil \\
\hline 3 & SERCA & $\begin{array}{c}\text { ASN 111, SER 731, SER335, ARG 334, GLU 732, THR } \\
\text { 247, ASP 245, LYS 712, THR } 242\end{array}$ & $\begin{array}{l}\text { SER 731, GLU 732, LYS } \\
\text { 712, THR } 242\end{array}$ & Nil \\
\hline 4 & SEIPIN & $\begin{array}{l}\text { LEU 90, PHE 66, PHE 59, LEU 412, THR 63, LEU 124, } \\
\text { MET 89, ILE 298, MET 39, SER 67, PHE 297, ALA 64, } \\
\text { GLY 294, ILE 68, ASP 65, PRO 413, SER 97, SER 84, PHE } \\
\text { 415, LEU 139, ALA 377, VAL 214, ILE 141, LEU 131, ILE } \\
\text { 414, LEU 86, TYR 127, ASP 407, }\end{array}$ & ALA 64 & Nil \\
\hline 5 & CaMkII & $\begin{array}{c}\text { GLU 168, LYS 268, CYS 273, HIS 269, GLN 274, GLN } \\
\text { 251, GLN 169, VAL 278, GLU 244, ALA 170, GLN 168, } \\
\text { PRO 243, THR 242, PRO 270, ASN 247, -HE 172, LE 162, } \\
\text { VAL 164, ARG 60, ARG 63. }\end{array}$ & LYS 268, GLU 163, & Nil \\
\hline 6 & Phospholamban & $\begin{array}{l}\text { ASN 30, ASN 27, LEU 28, LEU 31, ILE 33, LEU 37, ASN } \\
34\end{array}$ & $\begin{array}{c}\text { ASN 34, ASN } 30 \text { AND ASN } \\
27\end{array}$ & Nil \\
\hline 7 & RYR2 & $\begin{array}{l}\text { GLU 84, PHE 12, ALA 15, GLU 11, LEU 18, GLU 14, } \\
\text { MET 145, PHE 92, ALA 88, LEU 112, VAL 108, VAL 91, } \\
\text { GLU } 87\end{array}$ & GLU 84, GLU 11, GLU 14 & Nil \\
\hline 8 & VGCC & $\begin{array}{l}\text { PRO 326, ILE 338, PHE 383, SEER 382, SER 330, GLU } \\
\text { 381, ARG 227, ALA 335, ASP 384, THR 332, PRO 336, } \\
\text { LEU 329, HIS 325, GLN 328, VAL 232, VAL 230, ILE } \\
\text { 323, LEU } 374\end{array}$ & NIL & Nil \\
\hline
\end{tabular}




\section{Conclusions}

The binding of DOX with enolase, negatively affected by adriamycin, impairs glycolysis. DOX bind with HMOX1 causes free iron accumulation. The free iron causes hemedriven toxicity and the oxidizing environment, leading to ROS formation and cell death. The binding of DOX with PINK1 causes decreased membrane potential leading to calcium accumulation. On the other hand, iron and calcium deficiency in the mitochondrial matrix causes ATP depletion by altering the Krebs cycle. Altered cardiac energy metabolism during DOX treatment apparently culminates in cardiomyopathy. Thus, our study concludes that the DOX disrupts the functions of PFK, $\alpha$-enolase, HMOX1, and PINK1, which leads to alteration in cardiac energetics, ensuing cardiomyopathy.

\section{Funding}

The authors acknowledge the Science and Engineering Research Board, Government of India (EMR/2016/003548) for financial support.

\section{Acknowledgments}

The authors acknowledge the Science and Engineering Research Board, Government of India (EMR/2016/003548) for financial support.

\section{Conflicts of Interest}

The authors declare no conflict of interest.

\section{References}

1. Cortés-Funes, H.; Coronado, C. Role of anthracyclines in the era of targeted therapy. Cardiovasc. Toxicol. 2007, 7, 56-60, https://doi.org/10.1007/s12012-007-0015-3.

2. Carvalho, C.; Santos, R.X.; Cardoso, S.; Correia, S.; Oliveira, P.J.; Santos, M.S.; Moreira, P.I. Doxorubicin: the good, the bad and the ugly effect. Curr. Med. Chem. 2009, 16, 3267-3285, https://doi.org/10.2174/092986709788803312.

3. Akthar, I.S.T.; Pichiah, P.B.T.; Arunachalam, S.; Raja, S. Adriamycin inhibits embryonic development in zebrafish through downregulation of Kruppel-like factor4. J. Biochem. Mol. Toxicol. 2019, 33, https://doi.org/10.1002/jbt.22235.

4. Mohan, U.P.; PB, T.P.; Iqbal, S.T.A.; Arunachalam, S. Mechanisms of Doxorubicin-Mediated Reproductive Toxicity-A Review. Reprod. Toxicol. 2021, 102, 80-89, https://doi.org/10.1016/j.reprotox.2021.04.003.

5. Prasanna, P.L.; Renu, K.; Abilash, V.G. New molecular and biochemical insights of doxorubicin-induced hepatotoxicity. Life Sci. 2020, 250, https://doi.org/10.1016/j.lfs.2020.117599.

6. Singal, P.; Li, T.; Kumar, D.; Danelisen, I.; Iliskovic, N. Adriamycin-induced heart failure: mechanisms and modulation. Mol. Cell. Biochem. 2000, 207, 77-86, https://doi.org/10.1023/a:1007094214460.

7. Cardinale, D.; Colombo, A.; Bacchiani, G.; Tedeschi, I.; Meroni, C.A.; Veglia, F.; Civelli, M.; Lamantia, G.; Colombo, N.; Curigliano, G. Early detection of anthracycline cardiotoxicity and improvement with heart failure therapy. Circulation 2015, 131, 1981-1988, https://doi.org/10.1161/circulationaha.114.013777.

8. Colombo, A.; Cipolla, C.; Beggiato, M.; Cardinale, D. Cardiac toxicity of anti-cancer agents. Curr. Cardiol. Rep. 2013, 15, https://doi.org/10.1007/s11886-013-0362-6.

9. Šimůnek, T.; Štěrba, M.; Popelová, O.; Adamcová, M.; Hrdina, R.; Geršl, V. Anthracycline-induced cardiotoxicity: overview of studies examining the roles of oxidative stress and free cellular iron. Pharmacol. reports 2009, 61, 154-171, https://doi.org/10.1016/s1734-1140(09)70018-0.

10. Renu, K.; Abilash, V.G.; PB, T.P.; Arunachalam, S. Molecular mechanism of doxorubicin-induced cardiomyopathy-An update. Eur. J. Pharmacol. 2018, 818, 241-253, https://doi.org/10.1016/j.ejphar.2017.10.043.

11. Koleini, N.; Kardami, E. Autophagy and mitophagy in the context of doxorubicin-induced cardiotoxicity. Oncotarget 2017, 8, https://doi.org/10.18632/oncotarget.16944.

12. Thabassum Akhtar Iqbal, S.; Tirupathi Pichiah, P.B.; Raja, S.; Arunachalam, S. Paeonol Reverses Adriamycin Induced Cardiac Pathological Remodeling through Notch1 Signaling Reactivation in H9c2 Cells 
and Adult Zebrafish Heart. Chem. Res. Toxicol. 2020, 33, 312-323, https://doi.org/10.1021/acs.chemrestox.9b00093.

13. Wallace, K.B.; Sardão, V.A.; Oliveira, P.J. Mitochondrial Determinants of Doxorubicin-Induced Cardiomyopathy. Circ. Res. 2020, 126, 926-941, https://doi.org/10.1161/circresaha.119.314681.

14. Russo, M.; Della Sala, A.; Tocchetti, C.G.; Porporato, P.E.; Ghigo, A. Metabolic aspects of anthracycline cardiotoxicity. Curr. Treat. Options Oncol. 2021, 22, 1-21, https://doi.org/10.1007/s11864-020-00812-1.

15. Arunachalam, S.; Tirupathi Pichiah, P.B.; Achiraman, S. Doxorubicin treatment inhibits PPAR $\gamma$ and may induce lipotoxicity by mimicking a type 2 diabetes-like condition in rodent models. FEBS Lett. 2013, 587, 105-110, https://doi.org/10.1016/j.febslet.2012.11.019.

16. van der Zanden, S.Y.; Qiao, X.; Neefjes, J. New insights into the activities and toxicities of the old anti-cancer drug doxorubicin. The FEBS journal 2021, 288, 6095-6111, https://doi.org/10.1111/febs.15583.

17. Goormaghtigh, E.; Chatelain, P.; Caspers, J.; Ruysschaert, J.M. Evidence of a complex between adriamycin derivatives and cardiolipin: possible role in cardiotoxicity. Biochem. Pharmacol. 1980, 29, 3003-3010, https://doi.org/10.1016/0006-2952(80)90050-7.

18. Kalyanaraman, B. Teaching the basics of the mechanism of doxorubicin-induced cardiotoxicity: Have we been barking up the wrong tree? Redox Biol. 2020, 29, https://doi.org/10.1016/j.redox.2019.101394.

19. Chandel, N.S. Glycolysis. Cold Spring Harb. Perspect. Biol. 2021, 13.

20. Bertram, R.; Pedersen, M.G.; Luciani, D.S.; Sherman, A. A simplified model for mitochondrial ATP production. J. Theor. Biol. 2006, 243, 575-586, https://doi.org/10.1016/j.jtbi.2006.07.019.

21. Boyman, L.; Karbowski, M.; Lederer, W.J. Regulation of mitochondrial ATP production: Ca2+ signaling and quality control. Trends Mol. Med. 2020, 26, 21-39, https://doi.org/10.1016/j.molmed.2019.10.007.

22. Tang, B.L. Glucose, glycolysis, and neurodegenerative diseases. J. Cell. Physiol. 2020, 235, 7653-7662, https://doi.org/10.1002/jcp.29682.

23. Kadenbach, B.; Ramzan, R.; Wen, L.; Vogt, S. New extension of the Mitchell Theory for oxidative phosphorylation in mitochondria of living organisms. Biochim. Biophys. Acta (BBA)-General Subj. 2010, 1800, 205-212, https://doi.org/10.1016/j.bbagen.2009.04.019.

24. Wittig, I.; Schägger, H. Supramolecular organization of ATP synthase and respiratory chain in mitochondrial membranes. Biochim. Biophys. Acta (BBA)-Bioenergetics 2009, 1787, 672-680, https://doi.org/10.1016/j.bbabio.2008.12.016.

25. Oexle, H.; Gnaiger, E.; Weiss, G. Iron-dependent changes in cellular energy metabolism: Influence on citric acid cycle and oxidative phosphorylation. Biochim. Biophys. Acta - Bioenerg. 1999, 1413, 99-107, https://doi.org/10.1016/S0005-2728(99)00088-2.

26. Morelli, A.M.; Ravera, S.; Panfoli, I. The aerobic mitochondrial ATP synthesis from a comprehensive point of view. Open Biol. 2020, 10, https://doi.org/10.1098/rsob.200224.

27. Nolfi-Donegan, D.; Braganza, A.; Shiva, S. Mitochondrial Electron Transport: Oxidative Phosphorylation, Mitochondrial Oxidant Production, and Methods of Measurement. Redox Biol. 2020, https://doi.org/10.1016/j.redox.2020.101674.

28. Mason, F.E.; Pronto, J.R.D.; Alhussini, K.; Maack, C.; Voigt, N. Cellular and mitochondrial mechanisms of atrial fibrillation. Basic Res. Cardiol. 2020, 115, 1-16, https://doi.org/10.1007/s00395-020-00827-7.

29. Fink, B.D.; Bai, F.; Yu, L.; Sivitz, W.I. Regulation of ATP production: dependence on calcium concentration and respiratory state. Am. J. Physiol. Physiol. 2017, 313, C146-C153, https://doi.org/10.1152/ajpcell.00086.2017.

30. Mohan, U.P.; Kunjiappan, S.; Pichiah, P.B.T.; Arunachalam, S. Adriamycin inhibits glycolysis through downregulation of key enzymes in Saccharomyces cerevisiae. 3 Biotech 2021, 11, 1-13, https://doi.org/10.1007/s13205-020-02530-9.

31. Akram, M. Mini-review on glycolysis and cancer. J. Cancer Educ. 2013, 28, 454-457, https://doi.org/10.1007/s13187-013-0486-9.

32. Doenst, T.; Nguyen, T.D.; Abel, E.D. Cardiac metabolism in heart failure: implications beyond ATP production. Circ. Res. 2013, 113, 709-724, https://doi.org/10.1161/circresaha.113.300376.

33. García, M.; Pujol, A.; Ruzo, A.; Riu, E.; Ruberte, J.; Arbós, A.; Serafín, A.; Albella, B.; Felíu, J.E.; Bosch, F. Phosphofructo-1-kinase deficiency leads to a severe cardiac and hematological disorder in addition to skeletal muscle glycogenosis. PLoS Genet 2009, 5, https://doi.org/10.1371/journal.pgen.1000615.

34. Jeyaseelan, R.; Poizat, C.; Wu, H.-Y.; Kedes, L. Molecular Mechanisms of Doxorubicin-induced Cardiomyopathy Selective suppression of reiske iron-sulfur protein, adp/atp translocase, and phosphofructokinase genes is associated with atp depletion in rat cardiomyocytes. J. Biol. Chem. 1997, 272, 5828-5832, https://doi.org/10.1074/jbc.272.9.5828.

35. Zhang, E.; Brewer, J.M.; Minor, W.; Carreira, L.A.; Lebioda, L. Mechanism of enolase: The crystal structure of asymmetric dimer enolase- 2-phospho-d-glycerate/enolase- phosphoenolpyruvate at 2.0 å resolution. Biochemistry 1997, 36, 12526-12534, https://doi.org/10.1021/bi9712450.

36. Piast, M.; Kustrzeba-Wójcicka, I.; Matusiewicz, M.; Banaś, T. Molecular evolution of enolase. Acta Biochim. Pol. 2005, 52, 507-513. 
37. Lebioda, L.; Stec, B. Mechanism of enolase: the crystal structure of enolase-magnesium-2phosphoglycerate/phosphoenolpyruvate complex at 2.2-. ANG. resolution. Biochemistry 1991, 30, 28172822, https://doi.org/10.1021/bi00225a012.

38. Gao, S.; Li, H.; Feng, X.; Li, M.; Liu, Z.; Cai, Y.; Lu, J.; Huang, X.; Wang, J.; Li, Q. $\alpha$-Enolase plays a catalytically independent role in doxorubicin-induced cardiomyocyte apoptosis and mitochondrial dysfunction. J. Mol. Cell. Cardiol. 2015, 79, 92-103, https://doi.org/10.1016/j.yjmcc.2014.11.007.

39. Converso, D.P.; Taillé, C.; Carreras, M.C.; Jaitovich, A.; Poderoso, J.J.; Boczkowski, J.; Converso, D.P.; Taillé, C.; Carreras, M.C.; Jaitovich, A. HO-1 is located in liver mitochondria and modulates mitochondrial heme content and metabolism. FASEB J. 2006, 20, 1236-1238, https://doi.org/10.1096/fj.05-4204fje.

40. Slebos, D.-J.; Ryter, S.W.; Van Der Toorn, M.; Liu, F.; Guo, F.; Baty, C.J.; Karlsson, J.M.; Watkins, S.C.; Kim, H.P.; Wang, X. Mitochondrial localization and function of heme oxygenase-1 in cigarette smokeinduced cell death. Am. J. Respir. Cell Mol. Biol. 2007, 36, 409-417, https://doi.org/10.1165/rcmb.20060214oc.

41. Kurumada, T.; Labbe, R.F. Fumarate reductase in the control of heme biosynthesis. Science 1966, 151, 12281229, https://doi.org/10.1126/science.151.3715.1228.

42. Sawicki, K.T.; Chang, H.; Ardehali, H. Role of heme in cardiovascular physiology and disease. J. Am. Heart Assoc. 2015, 4, https://doi.org/10.1161/JAHA.114.001138.

43. Ichikawa, Y.; Ghanefar, M.; Bayeva, M.; Wu, R.; Khechaduri, A.; Naga Prasad, S. V.; Mutharasan, R.K.; Jairaj Naik, T.; Ardehali, H. Cardiotoxicity of doxorubicin is mediated through mitochondrial iron accumulation. J. Clin. Invest. 2014, 124, 617-630, https://doi.org/10.1172/JCI72931.

44. Sadrzadeh, S.M.; Graf, E.; Panter, S.S.; Hallaway, P.E.; Eaton, J.W. Hemoglobin. A biologic fenton reagent. J. Biol. Chem. 1984, 259, 14354-14356.

45. Keizer, H.G.; Pinedo, H.M.; Schuurhuis, G.J.; Joenje, H. Doxorubicin (adriamycin): a critical review of free radical-dependent mechanisms of cytotoxicity. Pharmacol. Ther. 1990, 47, 219-231, https://doi.org/10.1016/0163-7258(90)90088-j.

46. Myers, C.E.; Gianni, L.; Simone, C.B.; Klecker, R.; Greene, R. Oxidative destruction of erythrocyte ghost membranes catalyzed by the doxorubicin-iron complex. Biochemistry 1982, 21, 1707-1713, https://doi.org/10.1021/bi00537a001.

47. Xu, X.; Persson, H.L.; Richardson, D.R. Molecular pharmacology of the interaction of anthracyclines with iron. Mol. Pharmacol. 2005, 68, 261-271, https://doi.org/10.1124/mol.105.013383.

48. Meneghini, R. Iron homeostasis, oxidative stress, and DNA damage. Free Radic. Biol. Med. 1997, 23, 783792, https://doi.org/10.1016/s0891-5849(97)00016-6.

49. Tretter, L.; Patocs, A.; Chinopoulos, C. Succinate, an intermediate in metabolism, signal transduction, ROS, hypoxia, and tumorigenesis. Biochim. Biophys. Acta (BBA)-Bioenergetics 2016, 1857, 1086-1101, https://doi.org/10.1016/j.bbabio.2016.03.012.

50. Carr, J.F.; Garcia, D.; Scaffa, A.; Peterson, A.L.; Ghio, A.J.; Dennery, P.A. Heme Oxygenase-1 Supports Mitochondrial Energy Production and Electron Transport Chain Activity in Cultured Lung Epithelial Cells. Int. J. Mol. Sci. 2020, 21, https://doi.org/10.3390/ijms21186941.

51. Gutman, M.; Kearney, E.B.; Singer, T.P. Regulation of succinate dehydrogenase activity by reduced coenzyme Q. Biochemistry 1971, 10, 2726-2732.

52. Claypool, S.M.; Koehler, C.M. The complexity of cardiolipin in health and disease. Trends Biochem. Sci. 2012, 37, 32-41, https://doi.org/10.1016/j.tibs.2011.09.003.

53. Paradies, G.; Paradies, V.; De Benedictis, V.; Ruggiero, F.M.; Petrosillo, G. Functional role of cardiolipin in mitochondrial bioenergetics. Biochim. Biophys. Acta (BBA)-Bioenergetics 2014, 1837, 408-417, https://doi.org/10.1016/j.bbabio.2013.10.006.

54. Paradies, G.; Paradies, V.; Ruggiero, F.M.; Petrosillo, G. Role of cardiolipin in mitochondrial function and dynamics in health and disease: molecular and pharmacological aspects. Cells 2019, 8, https://doi.org/10.3390/cells8070728.

55. Jung, K.; Reszka, R. Mitochondria as subcellular targets for clinically useful anthracyclines. Adv. Drug Deliv. Rev. 2001, 49, 87-105, https://doi.org/10.1016/s0169-409x(01)00128-4.

56. Guven, C.; Sevgiler, Y.; Taskin, E. Mitochondrial dysfunction associated with doxorubicin. In: Mitochondrial diseases; IntechOpen, 2018; pp. 323, https://doi.org/10.5772/intechopen.80284.

57. Choi, S.Y.; Gonzalvez, F.; Jenkins, G.M.; Slomianny, C.; Chretien, D.; Arnoult, D.; Petit, P.X.; Frohman, M.A. Cardiolipin deficiency releases cytochrome $\mathrm{c}$ from the inner mitochondrial membrane and accelerates stimuli-elicited apoptosis. Cell Death Differ. 2007, 14, 597-606, https://doi.org/10.1038/sj.cdd.4402020.

58. Paradies, G.; Paradies, V.; Ruggiero, F.M.; Petrosillo, G. Mitochondrial bioenergetics and cardiolipin alterations in myocardial ischemia-reperfusion injury: implications for pharmacological cardioprotection. Am. J. Physiol. Circ. Physiol. 2018, 315, H1341-H1352, https://doi.org/10.1152/ajpheart.00028.2018.

59. Gandhi, S.; Wood-Kaczmar, A.; Yao, Z.; Plun-Favreau, H.; Deas, E.; Klupsch, K.; Downward, J.; Latchman, D.S.; Tabrizi, S.J.; Wood, N.W. PINK1-associated Parkinson's disease is caused by neuronal vulnerability to calcium-induced cell death. Mol. Cell 2009, 33, 627-638, https://doi.org/10.1016/j.molcel.2009.02.013. 
60. Gegg, M.E.; Cooper, J.M.; Schapira, A.H. V; Taanman, J.-W. Silencing of PINK1 expression affects mitochondrial DNA and oxidative phosphorylation in dopaminergic cells. PLoS One 2009, 4, https://doi.org/10.1371/journal.pone.0004756.

61. Piccoli, C.; Sardanelli, A.; Scrima, R.; Ripoli, M.; Quarato, G.; D’Aprile, A.; Bellomo, F.; Scacco, S.; De Michele, G.; Filla, A. Mitochondrial respiratory dysfunction in familiar parkinsonism associated with PINK1 mutation. Neurochem. Res. 2008, 33, 2565-2574, https://doi.org/10.1007/s11064-008-9729-2.

62. Siddall, H.K.; Yellon, D.M.; Ong, S.B.; Mukherjee, U.A.; Burke, N.; Hall, A.R.; Angelova, P.R.; Ludtmann, M.H.R.; Deas, E.; Davidson, S.M.; Mocanu, M.M.; Hausenloy, D.J. Loss of PINK1 Increases the Heart's Vulnerability to Ischemia-Reperfusion Injury, PLoS One 2013, 8, https://doi.org/10.1371/journal.pone.0062400.

63. Yin, J.; Guo, J.; Zhang, Q.; Cui, L.; Zhang, L.; Zhang, T.; Zhao, J.; Li, J.; Middleton, A.; Carmichael, P.L. Doxorubicin-induced mitophagy and mitochondrial damage is associated with dysregulation of the PINK1/parkin pathway. Toxicol. Vitr. 2018, 51, 1-10, https://doi.org/10.1016/j.tiv.2018.05.001.

64. Koyano, F.; Okatsu, K.; Kosako, H.; Tamura, Y.; Go, E.; Kimura, M.; Kimura, Y.; Tsuchiya, H.; Yoshihara, H.; Hirokawa, T. Ubiquitin is phosphorylated by PINK1 to activate parkin. Nature 2014, 510, 162-166, https://doi.org/10.1038/nature13392.

65. Kushnir, A.; Marks, A.R. The ryanodine receptor in cardiac physiology and disease. Advances in pharmacology (San Diego, Calif.) 2010, 59, 1-30, https://doi.org/10.1016/s1054-3589(10)59001-x.

66. Heeman, B.; Van den Haute, C.; Aelvoet, S.-A.; Valsecchi, F.; Rodenburg, R.J.; Reumers, V.; Debyser, Z.; Callewaert, G.; Koopman, W.J.H.; Willems, P.H.G.M. Depletion of PINK1 affects mitochondrial metabolism, calcium homeostasis and energy maintenance. J. Cell Sci. 2011, 124, 1115-1125, https://doi.org/10.1242/jcs.078303.

67. Rizzuto, R.; De Stefani, D.; Raffaello, A.; Mammucari, C. Mitochondria as sensors and regulators of calcium signalling. Nat. Rev. Mol. cell Biol. 2012, 13, 566-578, https://doi.org/10.1038/nrm3412.

68. Hayashi, T.; Su, T.-P. Sigma-1 receptor chaperones at the ER-mitochondrion interface regulate $\mathrm{Ca} 2+$ signaling and cell survival. Cell 2007, 131, 596-610, https://doi.org/10.1016/j.cell.2007.08.036.

69. Park, I.Y.; Kim, E.J.; Park, H.; Fields, K.; Dunker, A.K.; Kang, C. Interaction between cardiac calsequestrin and drugs with known cardiotoxicity. Mol. Pharmacol. 2005, 67, 97-104, https://doi.org/10.1124/mol.104.005744.

70. Olson, R.D.; Gambliel, H.A.; Vestal, R.E.; Shadle, S.E.; Charlier, H.A.; Cusack, B.J. Doxorubicin cardiac dysfunction. Cardiovasc. Toxicol. 2005, 5, 269-283.

71. Sag, C.M.; Köhler, A.C.; Anderson, M.E.; Backs, J.; Maier, L.S. CaMKII-dependent SR Ca leak contributes to doxorubicin-induced impaired Ca handling in isolated cardiac myocytes. J. Mol. Cell. Cardiol. 2011, 51, 749-759, https://doi.org/10.1016/j.yjmcc.2011.07.016.

72. Wallace, K.B. Adriamycin-induced interference with cardiac mitochondrial calcium homeostasis. Cardiovasc. Toxicol. 2007, 7, 101-107, https://doi.org/10.1007/s12012-007-0008-2.

73. Kim, S.-Y.; Kim, S.-J.; Kim, B.-J.; Rah, S.-Y.; Chung, S.M.; Im, M.-J.; Kim, U.-H. Doxorubicin-induced reactive oxygen species generation and intracellular $\mathrm{Ca} 2+$ increase are reciprocally modulated in rat cardiomyocytes. Exp. Mol. Med. 2006, 38, 535-545, https://doi.org/10.1038/emm.2006.63.

74. Arai, M.; Tomaru, K.; Takizawa, T.; Sekiguchi, K.; Yokoyama, T.; Suzuki, T.; Nagai, R. Sarcoplasmic reticulum genes are selectively down-regulated in cardiomyopathy produced by doxorubicin in rabbits. $J$. Mol. Cell. Cardiol. 1998, 30, 243-254, https://doi.org/10.1006/jmcc.1997.0588. 